\title{
Bahan Ajar Menggunakan Sparkol Videoscribe Berbasis Multimedia untuk Technoprenuership Peningkatan Mutu Pembelajaran
}

\author{
Didik Siswanto ${ }^{1}$, Muhamad Sadar ${ }^{2}$, Lasri Nijal ${ }^{3}$ \\ 1,2,3 Universitas Lancang Kuning, Pekanbaru, Indonesia \\ Jalan Yos Sudarso KM. 08 Rumbai, Pekanbaru-Riau, (0761) 53108 -53236 \\ email ${ }^{1}$ didik@unilak.ac.id, ${ }^{2}$ sadarzen@unilak.ac.id, ${ }^{3}$ lasrinijal@unilak.ac.id
}

\begin{abstract}
Abstrak: Video Scrabe berbasis multimedia sebagai penunjang para dosen dalam melaksanakan pengajaran di dalam kelas. Dengan pemanfaatan dan pengembangkan teknik, strategi, metode, dan media pembelajaran yang tepat, Dosen - Dosen di PG PAUD dapat aktif berinteraksi dengan sumber belajarnya dan mampu meningkatkan kualitas mereka sebagai manusia yang terdidik. Dalam hal ini, pemanfaatan media yang menarik dan tepat guna dalam proses pembelajaran pastinya akan memiliki dampak positif yang akan sangat berpotensi meningkatkan mUnilaku pendidikan. Para dosen di kampus mitra ini sangat membUnilakuhkan adanya wadah dan upaya nyata bagi pengembangan kompetensi mereka khususnya dalam hal pemanfaatan dan pengembangan media pembelajaran demi memenuhi kewajiban meningkatkan hasil dari proses pembelajaran. Oleh sebab itu, tim pengusul program Pengabdian Kepada Masyarakat menawarkan solusi berupa Pelatihan Pembuatan bahan ajar Berbasis Multimedia Untuk dosen PAUD Universitas Lancang Kuning Pekanbaru. Di mana program ini diharapkan mampu menjadi wadah dan inspirasi bagi para dosen di kampus mitra untuk membuat bagaimana bahan ajar mereka lebih kekinian dan lebih menonjolkan letak identiksifitas terhadap materi, yang mana nanti Dosen - Dosen di PG PAUD dapat mengikuti proses belajar dan mengajar dengan rasa yang berbeda. dan dosen pun lebih mampu menghasilkan karya yang dapat merangsang daya Tarik dan focus Dosen - Dosen di PG PAUD. Sebagai tenaga pendidik memberikan sosialisasi dan sekaligus pendampingan mengenai bagaimana pembuatan bahan ajar berbasis multimedia dengan bantuan media aplikasi sparkol videoscribel dan Powtoon menjadi solusi yang baik untuk dapat mewujudkan generasi milenial yang terdepan, sehingga dari setiap materi mata kuliah terdapat bahan-bahan ajar yang menarik dan pastinya sagat dapat bermanfaat.
\end{abstract}

Kata Kunci: Multimedia, Sparkol Video Scrube, PAUD

\begin{abstract}
Multimedia-based Video Scrabe to support lecturers in carrying out teaching in the classroom. By utilizing and developing appropriate techniques, strategies, methods, and learning media, Lecturers at PG PAUD can actively interact with their learning resources and be able to improve their quality as educated humans. In this case, the use of attractive and effective media in the learning process will certainly have a positive impact which has the potential to greatly improve educational behavior. The lecturers at this partner campus really need a place and real effort for the development of their competence, especially in terms of utilizing and developing learning media in order to fulfill the obligation to improve the results of the learning process. Therefore, the team of proposers for the Community Service program offered a solution in the form of Multimedia-Based Training on Making teaching materials for PAUD lecturers at Lancang Kuning University Pekanbaru. Where this program is expected to be able to become a forum and inspiration for lecturers on partner campuses to make their teaching materials more current and to further highlight the location of identification of the material, which later the Lecturers at PG PAUD can take part in the learning and teaching process with a sense of belonging. different. and lecturers are also better able to produce works that can stimulate the attraction and focus of Lecturers at PG PAUD. As educators provide socialization and at the same time assistance regarding how to make multimediabased teaching materials with the help of the Sparkol Videoscribel and Powtoon application
\end{abstract}


media is a good solution to be able to realize the foremost millennial generation, so that from each subject matter there are interesting and certainly teaching materials. sagat can be useful.

Keywords: Multimedia, Sparkol Video Scrube, PAUD

\section{Pendahuluan}

Pendidikan pada jenjang strata satu mewajibkan tenaga pendidik dan peserta didik jauh lebih kreatif, kreatifitas yang tinggi dari anak didik ini membuat perbedaan gaya belajar nya juga pada tingkatan ini, dibanding dengan siswa dan pelajar pada jenjang dibawah nya. Dosen dan Dosen - Dosen di PG PAUD harus mampu mengexplor diri dan meningkatkan wawasan ilmu pengetahuan dari segala bidang. Terutama pada era revolusi industry 4.0 sekarang ini yang telah meluas di lingkungan masyarakat membuat wajibnya dosen dan Dosen - Dosen di PG PAUD memahami dan mengetahui teknologi yang semakin hari semakin jauh berevolusinya, tidak menutup kemungkinan juga pada dosen dan Dosen - Dosen di PG PAUD yang bukan basic nya berkampus di jurusan teknologi informatika, seperti jurusan sosial (ekonomi, manajemen akuntansi,administrasi, keguruan dan hukum) jadi ini menunjukan bahwa dunia pendidikan sekarang ini juga membutuhkan wawasan dan pengetahuan IT meskipun dosen dan Dosen - Dosen di PG PAUD tersebut dari background pendidikan nya bukan komputer dan IT, dibuktikan dengan setiap kurikulum pada setiap kampus telah menyematkan di kurikulum mereka dengan mata kuliah komputer dan Sains demi penyetaraan kemampuan pemahaman anak didik terhadap IT yang semakin canggih.

Universitas lancang kuning yang disingkat dengan UNILAK merupakan kampus swasta yang sudah lama berdiri yang berlokasi di kecamatan rumbai, tepatnya di JL.Yossudarso KM.08 dan bersebelahan dengan kampus politeknik Caltex riau. Pada kampus ini penerapan proses belajar dan mengajar telah dilaksanakan dengan sistem tatap muka yang mana biasanya / pada umumnya dosen memberikan bahan ajar mereka menggunakan slide power point text (PPT).

Mitra pengabdian tim ini merupakan salah satu prodi dari kampus universitas lancing kuning, yaitu berada pada fakultas keguruan dan ilmu pendidikan (FKIP) pada prodi Pendidikan anank usia dini (PAUD), kenapa pada prodi paud yang kami pilih....?

Yaitu karena penerapan nya amat terasa menarik dan berdampak baik di banding prodi lain, serta pada wujud penerapannya semua peserta didik di ruang lingkup paud suka sekali dengan hal-hal unik dan menarik sehingga membuat anak-anak jauh lebih happy dan enjoy di dalam mengikuti proses belajar. Akan tetapi kedepan tim pengabdian juga akan memberikan pelatihan dan kursus yang sama kepada prodi-prodi lain yang membutuhkan, apalagi pada masa pandemi ini (covid -19) setiap dosen / tenaga pendidik di tuntut memberikan materi dan bahan ajar mereka dengan berbasis multimedia sehingga walaupun tidak berhadapan langsung antara dosen dan Dosen - Dosen di PG PAUD tetapi pesan dari materi itu tersampaikan dengan jelas, lengkap dan menarik.

Sementara itu penerapan Bahan Ajarberbasis multimedia dapat diterapkan dengan poenerapan Sparkol Video Scribe dan Poowton yang sering diistilah dengan media pembelajaran yang penerapannya dapat digunakan dalam proses pembelajaran seperti laptop dan LCD proyektor pada mata Kuliah yang di ajarkan dosen FKIP Paud universitas lancing kuning, ataupun bahanajar ini nantinya bias di sematkan saja ke sistem pendukung pembelajaran yang dimiliki oleh kampus Unilak, (Blended Learning) ataupun dosen bias mengirimkan bahan ajar mereka ini ke WAG mata kuliah bersama Dosen Dosen di PG PAUD. 
Berdasarkan hasil obervasi dan interview, maka tim pengusul program pengabdian kepada Masyarakat (PKM) menawarkan sebuah solusi terhadap permasalahan yang dihadapi oleh Dosen - Dosen di PG PAUD di Kampus Universitas lancang kuning (UNILAK) Pekanbaru, melalui kegiatan pendampingan pembuatan Bahan Ajarberbasis multimedia dengan menggunakan aplikasi video scrube. Kegiatan ini dipandang sangat perlu karena diharapkan mampu memberikan kontribusi bagi Para Dosen di PG Paud FKIP Unilak tersebut khususnya dalam memperoleh keterampilan yang baik dalam membuat media pembelajaran berbasis multimedia.

\section{Metode}

Metode pelaksanaan pengabdian ini dengan metode teori dan praktek dengan rincian sebagai berikut:

1. Melakukan pembekalan pemahaman bagi peserta mengenai bagaimana cara serta Tips and Trik membuat sebuah biografi berbasis multimedia yang baik. (Sosialisasi) Mengenalkan apa itu Sparkol Videoscribe secara lengkap.

2. Melakukan pengregistrasian pada aplikasi Sparkol Videoscube dan test pengetahuan dasar dari peserta pelatihan.

3. Pelatihan langsung di labtob masing-masing peserta,dan di PC labor yang dipandu oleh pemateri secara step by step dan ditampilkan di projector berupa layar TV yang sudah tersedia.

4. Peserta pelatihan di uji dengan membuat hasil biografi yang menarik dengan tema dan konsep yang mereka sukai.

5. Penyebaran kuisioner kepada seluruh peserta pelatihan terhadap apa yang sudah di dapat.

\section{Hasil dan Pembahasan}

Pada saat pelaksanaan kegiatan ini penulis dan tim banyak sekali mendapatkan aprisiasi, terutama oleh para peserta dan sekaligus oleh ketua Prodi PG PAUD Pekanbaru yang merasa dapat mengupgrade pengetahuan Dosen - Dosen di PG PAUD mereka dengan kemajuan media pembelajaran yang interaktif dengan pemanfaatan alpikasi pendukung yang sangat mensuport output dari media pengajaran dosen- dosen mereka.

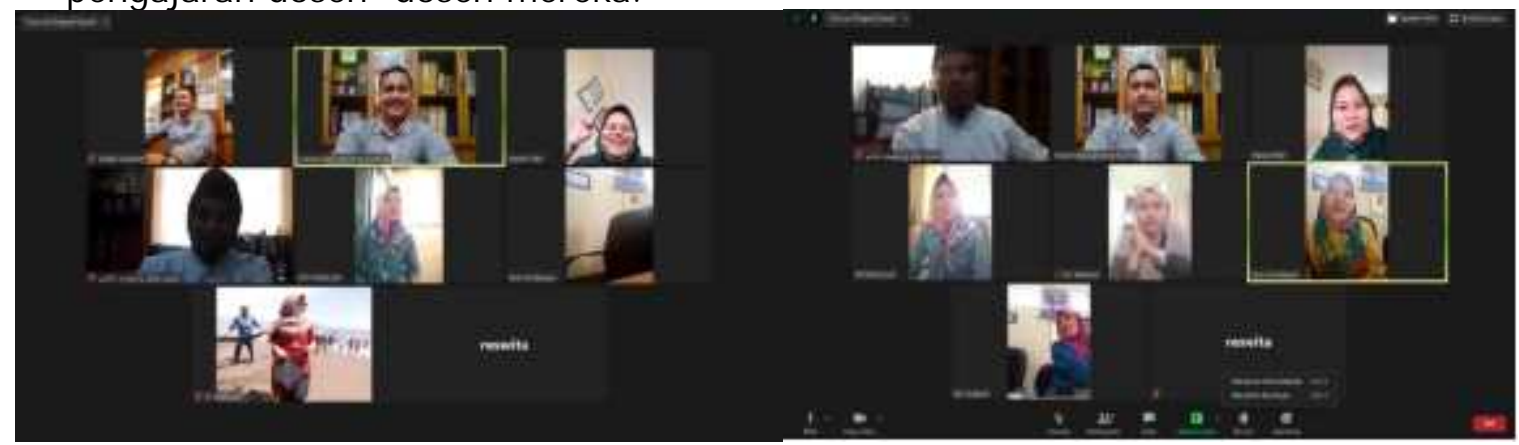

Gambar 1. Pelaksanaan Pengabdian

Adapun pelaksanaan kegiatan ini di lakukan by aplikasi Zoom Meeting, di karenakan masih belum kondusifnya pertemuan dan mengikuti protocol kesehatan covid -19 , dengan harapan segala informasi yang telah diberikan dapat dii manfaatkan dengan semaksimal mungkin. 
Tahapan pada pembuatan media pembelajaran berbasis multimedia slide master dilakukan dengan tahapan yang sangat terstruktur dengan langkah-langkah antara lain sebagai berikut:

- Untuk dapat menggunakan aplikasi sparkol videoscribe, langkah awal yang harus dilakukan adalah membuat akun pada sparkol.

- Silahkan kunjungi laman www.sparkol.com kemudian klik menu accoonf yang terdaftar pada bagian pojok kanan atas.

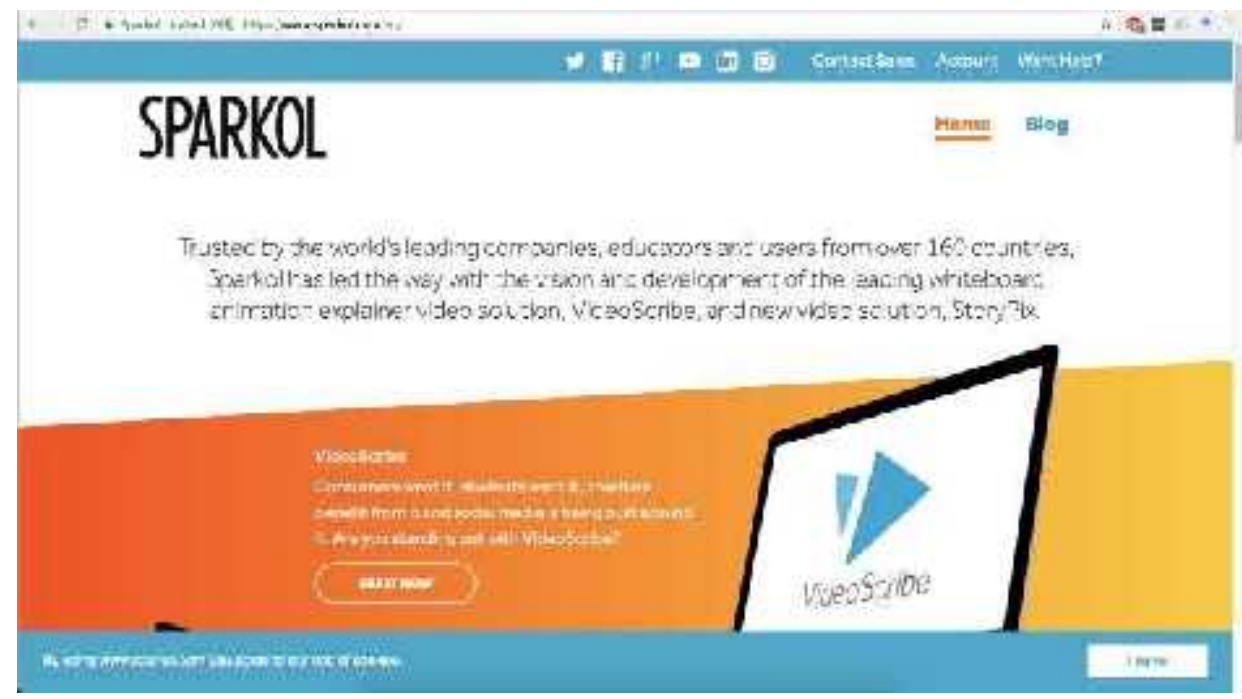

Gambar 2. Tampilan Menu Login Aplikasi Sparkol

- Apabila sudah memiliki akun pada sparkol dapat langsung login, apabila belum silakan klik "Sign Up Here

- Buka Aplikasi Videoscribe yang telah terinstall, akan muncul tampilan login.

- Klik login untuk dapat menggunakan versi offline.

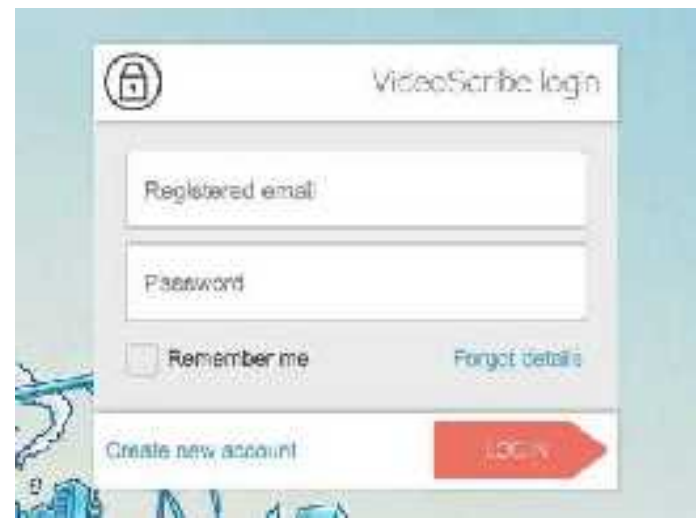

Gambar 3. Tampilan Login

- Secara Detail penulis lampirkan di lampiran pendukung (Tutorial Lengkap Penggunaan Sparkol)

- Kemudian desainlah setiap step menu yang dibuat sehingga sesuai dengan keinginan kita. 
Contohnya step 1 diatas untuk menempatkan animasi permainan tangan dan mengatur gerak laju maupun lambatnya putaran video dan gerakan tangan tersebut.

Tingkat keberhasilan dari pelatihan pembuatan biografi berbasis multimedia diukur menggunakan kuisioner yang diberikan kepada peserta pelatihan. Hasil perhitungan kuisioner ini nantinya akan dapat menentukan seberapa jauh pemahaman peserta terhadap materi dan pelatihan yang di dapat dalam proses yang sudah penulis rincikan dan terangkan tersebut.

Pada kuisioner yang disebar ini diberikan pertanyaan sebanyak 10 total pertanyaan yang terdiri dari 2 tahapan daftar pertanyaan, yaitu 5 pertanyaan di. Pertanyaan Umum, dan 5 lagi pertanyaan Pertanyaan Khusus

Skor untuk setiap jawaban adalah :

1 = Sangat Tidak Setuju (STS)

2 = Tidak Setuju (TS)

$3=$ Kurang Setuju (KS)

4 = Setuju (S)

5 = Sangat Setuju (SS)

Jumlah responden 11 orang sehingga didapat hasil skor dari untuk pertanyaan yang diajukan kepad responden adalah sebagai berikut :

Tabel 1. Rekapan Hasil Quisioner Peserta

\begin{tabular}{|c|c|c|c|c|c|c|c|c|c|c|c|}
\hline \multirow[t]{2}{*}{$\mathrm{Na}$} & \multirow[t]{2}{*}{ Nama Peserta } & \multicolumn{5}{|c|}{ Pertainsaan Ummin } & \multicolumn{5}{|c|}{ Pertanyzan Khasus } \\
\hline & & PI & $\mathbf{P 2}$ & P3 & P4 & P5: & $\mathrm{P} 6$ & P7 & P8 & Py & P10 \\
\hline $\mathrm{L}$ & Falem Film & 4 & 5 & 4 & 5 & 5 & 4 & 4 & 5 & 3 & 4 \\
\hline 2. & Sean & 5 & 4 & 4 & 5 & 5 & 4 & 4 & 5 & 2 & 4 \\
\hline 3. & Sni Watyumi & 4 & 4 & 4 & 5 & 5 & 4 & 4 & 5 & 3 & 4 \\
\hline 4 & Situ Faudia & 5 & 4 & 4 & 4 & 4 & 4 & 4 & 4 & 4 & 5 \\
\hline 5. & Sarmini & 5 & 7 & 7 & $\pi$ & $\pi$ & 4 & 7 & 4 & T & 4 \\
\hline 6. & Yesi & 4 & 4 & 4 & 5 & 5 & 4 & 4 & 4 & 3 & 4 \\
\hline 7. & Rleawita & 4 & 4 & 4 & 4 & 4 & 4 & 4 & 4 & 3 & 4 \\
\hline
\end{tabular}

Maka dari data diatas dapat ditarik kesimpulan yaitu bahwa semua peserta pelatihan memahami apa itu media pembelajaran berbasis multimedia dan memahami cara pengerjaan dan step-step pembuatan slide master, serta menginginkan penerapannya segera di realisasi, seperti hasil dari table dibawah ini.

Grafik trasil perugisian kuisioner Perser la Pelalifan

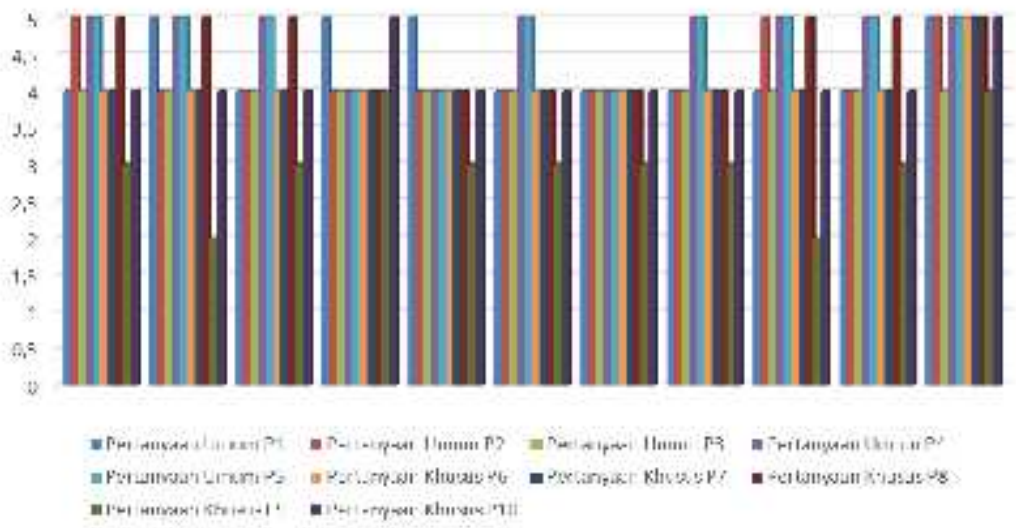

Grafik 1. Rekapan grafik hasil Quisione 


\section{Kesimpulan}

Berdasarkan hasil data dari penyebaran kuisioner, maka penulis dapat mengambil beberapa kesimpulan yaitu :

1. Pengetahuan peserta pelatihan tentang pembuatan biografi multimedia menggunakan aplikasi sparkol videoscube berbasis offline secara keseluruhan mengalami peningkatan.

2. Dengan adanya pelatihan ini dapat meningkatkan semangat Dosen - Dosen di PG PAUD didalam TAP (Tugas Akhir Project) sehingga mendorong Dosen - Dosen di PG PAUD untuk bersemangat menyelesaikan studynya.

3. Antusiasme para peserta pelatihan ini menunjukan peningkatan yang signifikan untuk merobah gaya kuliah yang dahulunya konvensional menjadi multimedia dan digital.

\section{Saran}

Dari kesimpulan diatas, maka penulis dapat memberikan beberapa saran sebagai berikut :

1. Peserta pelatihan harus sering membuat dan mencoba mengaplikasikan pembuatan bahan ajar berbasis multimedia menggunakan aplikasi sparkol videoscube berbasis offline secaraberkelanjutan di tiap-tiap project yang mereka miliki, sehingga membuat peserta semakinmahir dan lancer.

2. Hendaknya pihak yang berkepentingkan mensosialisasikan penggunaan media pembelajaran berbasis multimedia ini kepada semua citivas akademika

\section{Ucapan Terima Kasih}

Terima akasih kepada Fakultas IImu Komputer Universitas Lancang Kuning yang telah membantu secara financial dalam pelaksanaan kegiatan Pengabdian Kepada Masyarakat ini, serta pimpinan LPPM (lembaga Penelitian dan Pengabdian Masyarakat), serta mitra pengabdian masyarakat ini, yaitu bagian keluarga besar universitas lancang kuning pada prodi PAUD (pendidikan anak usia dini) di Fakultas Keguruan FKIP. Dan terimakasih kepada pimpinan serta rekan - rekan tenaga pendidik yang mau meluangkan waktunya untuk mengikuti kegiatan IbM.

\section{Daftar Pustaka}

Andriani, r., \& kasriyati, d. (2018). Pembuatan media pembelajaran berbasis multimedia bagi Dosen - Dosen di PG PAUD kampus dasar (sd) kecamatan rumbai kota pekanbaru provinsi riau. J-abdipamas (jurnal pengabdian kepada masyarakat), 2(2), 119-126.

Arsyad, azhar. 2002. Media pembelajaran. Jakarta: pt. Raja grafindo persada.

Gerlach \& elly. 1980. Teaching and media. Englewood cliffs, new jersey: prentice hall, inc

Kurniawan, k., andriani, r., \& kasriyati, d. (2017). Pengembangan media animasi untuk pembelajaran bahasa inggris sekecamatan rumbai kota pekanbaru. Dinamisia: jurnal Pengabdian kepada masyarakat, 1(1, des), 68-73.

arsyad, azhar. 2002. Media pembelajaran. Jakarta: pt. Raja grafindo persada gerlach \& elly. 1980. Teaching and media. Englewood cliffs, new jersey: prentice hall, inc 
kurniawan, nanang. 2014. Kurikulum 2011 dan pergeseran peran Dosen-Dosen di $\quad P G \quad P A U D$. Didapat dari: http://bangka.tribunnews.com/2014/03/27/kurikulum-2011-dan-pergeseran-peranDosen - Dosen di PG PAUD

natasya, eka putri utami. 2015. Media pembelajaran berbasis multimedia. Didapat dari: http://ekanatasya999.blogspot.co.id/2015/06/media-pembelajaran-berbasismultimedia_7.html

rusman, dkk. 2011. Pembelajaran berbasis teknologi informasi dan komunikasi: mengembangkan profesionalisme Dosen - Dosen di PG PAUD. Jakarta: pt. Rajagrafindo persada.

sa'diyah, halimatus. 2015. Peran pendidikan pada era globalisasi. Didapat dari: http://halya76.blogspot.co.id/2015/10/makalah-peran-pendidikan-padaera_6.html

smaldino, sharon e, et all. 2005. Instructional technology and media for learning. New Jersey: pearson prentice hall.

soedijarto. 2011. Profesionalisme Dosen - Dosen di PG PAUD (pendidik) dalam era globalisasi, implikasi, peluang dan tantangannya. Didapat dari: www.ispi.or.id/2011/11/21/profesionalisme-Dosen - Dosen di PG PAUDpendidikdalam-era-globalisasi-implikasi-peluang-dan-tantanganny 